\title{
HUBUNGAN ANTARA TEKANAN EKONOMI DAN MEKANISME KOPING DENGAN KESEJAHTERAAN KELUARGA WANITA PEMETIK TEH
}

\author{
Correlation between Economic Pressure and Coping Mechanism with Family \\ Welfare of Plantation Women Worker
}

\author{
FIRDAUS $^{1}$, EUIS SUNARTI ${ }^{2^{*}}$ \\ ${ }^{1}$ Program Studi Gizi Masyarakat dan Sumberdaya Keluarga, Fakultas Pertanian, \\ Institut Pertanian Bogor, Kampus Dramaga, Bogor 16680 \\ ${ }^{2}$ Staf Pengajar Departemen Ilmu Keluarga dan Konsumen, Fakultas Ekologi \\ Manusia, Institut Pertanian Bogor, Jalan Lingkar Kampus IPB Dramaga, \\ Bogor 16680
}

\begin{abstract}
Study in correlation between economic pressure and coping mechanism and its impact to family welfare in peasant in Indonesia are still less likely to be done. The general objective of this research was to analyze the correlation between economic pressure, financial management, and coping mechanism with family welfare of plantation women workers. This was cross sectional study that involved 87 families of plantation women workers who had under-6 years old children as samples. The data which was collected in April 2008 consists of primary and secondary data. The primary data consists of economic pressure, financial management, and coping mechanism that taken by using structured questionnaire. Result of the research shows that there are significant correlation between family size with economic pressure and between economic pressure with family welfare. It means that the bigger family size, then higher level economic pressure, and then lower the level of family welfare. There are positive significant correlation between education level with financial management and between financial management with family welfare. There are also negative significant correlation between sample's age with subjective and objective economic pressure, and positive significant correlation between economic pressure with coping mechanism in reducing food and non-food expenditure.
\end{abstract}

Key words: coping mechanism, economic pressure, financial management, plantation women worker, family welfare

\section{PENDAHULUAN}

Indonesia dikenal sebagai negara agraris dimana persentase terbesar penduduknya masih bermata pencaharian sebagai petani. Sebagian besar petani adalah petani kecil yang berpendapatan rendah dan bertempat tinggal di pedesaan. Selain pemilik dan atau penggarap lahan sempit, buruh tani juga termasuk dalam kategori petani kecil. Pada umumnya penghasilan petani kecil (juga buruh tani) sangat rendah, sehingga tergolong ke dalam keluarga miskin. Oleh karenanya petani kecil di pedesaan penyumbang sebagian besar angka kemiskinan di pedesaan. Data BPS
(2007) menunjukkan bahwa angka kemiskinan pedesaan lebih besar dibandingkan di perkotaan.

Krisis ekonomi global melanda seluruh sektor usaha, tidak terkecuali sektor pertanian dan perkebunan. Dalam batas tertentu krisis tersebut berdampak terhadap permintaan dan harga hasil perkebunan, yang pada akhirnya akan berdampak terhadap volume pekerjaan buruh lepas seperti para pemetik teh, yang sebagian besar adalah perempuan. Volume pekerjaan yang terpengaruh adalah yang berkaitan dengan perawatan tanaman teh. Perempuan pemetik teh umumnya bekerja selama tujuh jam per hari untuk memperoleh penghasilan 
sekitar Rp 13.000,00 per hari atau menyumbang sekitar $46 \%$ dari pendapatan keluarga. Walaupun sudah bekerja dengan jam kerja penuh, bahkan seringkali melakukan pekerjaan tambahan di sore harinya, namun sebagian besar keluarga wanita pemetik teh masih tergolong miskin (Sunarti 2008).

Terdapat kajian yang telah dilakukan mengenai keterkaitan pendapatan keluarga dan tekanan ekonomi keluarga serta dampaknya terhadap kesejahteraan keluarga. Demikian pula kajian mengenai keterkaitan pengelolaan keuangan dan mekanisme koping keluarga terhadap kesejahteraan keluarga. Namun demikian, masih jarang dilakukan kajian mengenai hal tersebut pada kelompok buruh tani, khususnya pada keluarga wanita pemetik teh.

Bagaimana keluarga wanita pemetik teh mengelola pendapatan keluarga dan menghadapi masalah keuangan keluarga untuk memenuhi kebutuhan pokoknya (kesejahteraan keluarga), menjadi penting untuk dielaborasi. Dokumentasi dan diseminasi hasil penelitian tersebut diharapkan dapat menjadi masukkan bagi berbagai pihak terkait dalam upaya meningkatkan kesejahteraan atau ketahanan keluarga wanita pemetik teh.

Penelitian ini bertujuan untuk menganalisis hubungan tekanan ekonomi, manajemen keuangan, mekanisme koping, dan kesejahteraan keluarga wanita pemetik teh; serta menganalisis hubungan antara peubah tersebut.

\section{METODE}

\section{Desain, Tempat, dan Waktu Penelitian}

Desain penelitian ini adalah cross sectional study. Penelitian dilaksanakan selama delapan bulan dan dimulai pada bulan Desember 2007 sampai Agustus 2008. Lokasi yang dipilih untuk penelitian ini yaitu PT Perkebunan Nusantara VIII Kebun Malabar, Desa Banjarsari, Kecamatan Pangalengan, Kabupaten Bandung, Propinsi Jawa Barat.

\section{Prosedur Penarikan Contoh}

Contoh dalam penelitian ini merupakan sebagian dari contoh penelitian "A Study of Plantation Women Workers: Socio Economic Status, Family Strength, Food Consumption, and
Children Growth and Development" (Sunarti 2008). Contoh dalam penelitian tersebut yaitu 87 wanita pemetik teh yang mempunyai anak usia di bawah 6 tahun dan tinggal di wilayah perkebunan Malabar.

\section{Jenis dan Cara Pengumpulan Data}

Data yang dikumpulkan meliputi tekanan ekonomi (objektif dan subjektif), manajemen keuangan, dan mekanisme koping (data primer); serta data karakteristik keluarga, kesejahteraan keluarga dan kondisi umum lokasi penelitian (data sekunder dari penelitian Sunarti 2008). Instrumen kesejahteraan keluarga merupakan modifikasi dari sebagian instrumen ketahanan keluarga yang disusun Sunarti (2001). Tekanan ekonomi keluarga menggunakan instrumen yang dikembangkan Sunarti et al. (2005), yang mana instrumen tekanan ekonomi keluarga objektif mengacu konsep kesulitan ekonomi menurut Lorenz et al. (1994). Sementara itu, instrumen manajemen keuangan dan mekanisme koping dikembangkan khusus untuk penelitian ini.

\section{Pengolahan dan Analisis Data}

Manajemen dan kontrol kualitas data dilakukan melalui pengkodean, entry, cleaning dan editing data dengan menggunakan Microsoft Office Excel 2003. Data dianalisis secara deskriptif dan inferensia (uji korelasi rank spearman) menggunakan komputer program Statistical Package for Social Sciences (SPSS) versi 12.0 for Windows.

\section{HASIL DAN PEMBAHASAN}

\section{Karakteristik Contoh dan Keluarga}

Tiga perempat contoh $(74,7 \%)$ dan hampir dua pertiga suami $(62,1 \%)$ berada pada tingkat dewasa muda (20-40 tahun), sementara sisanya berada pada tingkat dewasa madya (40-65 tahun). Enam dari sepuluh contoh maupun suami hanya tamat sekolah dasar, bahkan masih terdapat dua orang contoh yang tidak pernah sekolah. Namun demikian terdapat sebagian kecil contoh (2,3\%) dan suami $(1,1 \%)$ yang menamatkan SMA. Hal tersebut menunjukkan bahwa secara umum tingkat pendidikan contoh dan suami tergolong rendah. 
Suami contoh bekerja sebagai buruh tani dan sisanya sebagai buruh non tani, pedagang, tukang ojeg, pegawai TU kantor, satpam, sopir angkot, mandor, staf kantor dan pensiunan. Adapula suami contoh yang tidak bekerja karena sakit menahun. Empat dari sepuluh contoh memilki keluarga kecil ( $<4$ orang), sementara lebih dari setengahnya (55\%) memiliki keluarga sedang (5-6 orang), dan hanya sekitar $5 \%$ contoh yang memilki keluarga besar ( $\geq 7$ orang). Ratarata jumlah anggota keluarga contoh adalah lima orang.

\section{Pendapatan Keluarga}

Rata-rata pendapatan contoh adalah Rp 396.858,00 per bulan dengan kisaran antara $\mathrm{Rp} 143.333,00$ sampai dengan Rp 782.500,00 per bulan. Sementara rata-rata pendapatan suami lebih tinggi yaitu $R p$ 469.195,00 dengan kisaran antara $\mathrm{Rp} \quad 125.000,00$ hingga Rp 1.152.500,00. Sumbangan pendapatan contoh berkisar antara 40-53\% terhadap pendapatan keluarga, hampir setara dengan sumbangan pendapatan suami. Rataan pendapatan per kapita per bulan adalah sebesar Rp 200.156,00 dengan kisaran pendapatan antara Rp 71.167,00 sampai dengan Rp 417.916,00.

Jika mengacu pada garis kemiskinan Jawa Barat yaitu sebesar Rp 158.579,00 per kapita per bulan (BPS 2007), maka hampir separuh keluarga contoh $(42,5 \%)$ termasuk dalam kategori miskin. Jika mengacu garis kemiskinan World Bank sebesar \$1/kapita/hari atau setara

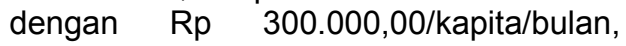
maka sebagian besar keluarga contoh $(85,0 \%)$ berada pada kategori miskin. Apalagi jika mengacu garis kemiskinan World Bank \$2/kapita/hari atau Rp 600.000,00/kapita/bulan, maka seluruh keluarga contoh terkategori miskin.

\section{Alokasi Pengeluaran Keuangan Keluarga}

Rata-rata pengeluaran pangan dan nonpangan keluarga contoh yaitu Rp 617.931,00 (80,1\% total pengeluaran) dan $\operatorname{Rp} 207.245,00$ atau $19,9 \%$ dari total pengeluaran. Kisaran pengeluaran keluarga contoh untuk pangan yaitu antara Rp 350.000,00 - Rp 1.140.000,00 per bulan, sedangkan kisaran pengeluaran untuk kebutuhan nonpangan keluarga yaitu antara $\mathrm{Rp} 33.333,00$ hingga Rp $947.666,00$ per bulan. Menurut Mangkuprawira (2002) porsi pengeluaran akan mencerminkan tingkat kesejahteraan masyarakat. Semakin besar porsi pengeluaran total keluarga hingga mencapai lebih dari $70 \%$ untuk kebutuhan pangan maka masyarakat termasuk golongan miskin.

\section{Tekanan Ekonomi Keluarga}

Dalam penelitian ini, tekanan ekonomi keluarga meliputi tekanan ekonomi objektif (yang diukur dengan pendapatan per kapita, rasio hutang dengan aset, status pekerjaan, dan kehilangan pekerjaan) dan tekanan ekonomi subjektif (persepsi terhadap tekanan atau kesulitan ekonomi keluarga). Instrumen untuk mengukur tekanan ekonomi keluarga mengacu pada penelitian Sunarti et al. (2005).

Sebaran contoh menurut tekanan ekonomi keluarga disajikan pada Tabel 1. Data menunjukkan selain 100\% contoh bekerja tidak tetap (buruh lepas), lebih dari setengah suami contoh juga pekerjaannya tidak tetap. Demikian juga walaupun $57,5 \%$ contoh tidak terkategori miskin menurut kategori BPS (2007) dan lebih dari setengah contoh memiliki pendapatan lebih besar dari pengeluaran, namun hampir semua contoh (95\%) memiliki hutang, dimana setengahnya memiliki hutang dengan nilai lebih dari setengah nilai aset yang dimiliki. Kondisi tersebut menunjukkan tingginya tekanan ekonomi objektif contoh.

Tekanan ekonomi subjektif mengukur persepsi contoh mengenai kondisi ekonomi keluarganya. Selain pengukuran tekanan ekonomi secara objektif, dipandang penting untuk mengukur tekanan ekonomi secara subjektif, mengingat persepsi seseorang terhadap suatu situasi, masalah dan kesulitan juga berbeda-beda. Persepsi seseorang mengindikasikan penerimaan seseorang terhadap keadaan dirinya.

Sebaran contoh menurut tekanan ekonomi subjektif disajikan pada Tabel 2 . Hampir semua contoh merasa kesulitan keuangan, sehingga terpaksa berhutang untuk memenuhi kebutuhan pokok seperti 
Tabel 1. Sebaran keluarga contoh berdasarkan tekanan ekonomi objektif

\begin{tabular}{lc}
\hline \multicolumn{1}{c}{ Dimensi Tekanan Ekonomi Objektif } & Persentase \\
\hline Pendapatan perkapita & \\
Miskin ( $\leq$ Rp158.579,00) & 42,5 \\
Tidak miskin (> Rp158.579,00) & 57,5 \\
\hline Status pekerjaan suami & 1,0 \\
Tidak bekerja & 50,6 \\
Tidak tetap & 48,3 \\
Tetap & \\
\hline Perbandingan pendapatan dan pengeluaran & 46,0 \\
Lebih besar pengeluaran & 54,0 \\
Lebih besar pendapatan & \\
\hline Perbandingan antara hutang dan Aset (Rasio) & 4,6 \\
Tidak berhutang & 49,4 \\
$<50 \%$ & 46,0 \\
$\geq 50 \%$ & \\
\hline
\end{tabular}

Tabel 2. Sebaran contoh yang merasakan tekanan ekonomi subjektif (persepsi contoh)

\begin{tabular}{clc}
\hline No & \multicolumn{1}{c}{ Pernyataan } & Persentase \\
\hline 1 & Merasa tidak puas dengan penghasilan keluarga & 64,4 \\
2 & Kecewa dengan ketidakmampuan suami dalam mencari penghasilan & 41,4 \\
3 & Merasa kurang puas dengan pekerjaan suami saat ini & 47,1 \\
4 & Membutuhkan bantuan keuangan dari orang tua atau saudara-saudara & 67,8 \\
& contoh atau suami & 78,4 \\
5 & Merasa penghasilan keluarga tidak mencukupi kebutuhan keluarga & 71,3 \\
7 & Berfikir bahwa contoh atau suami perlu mencari pekerjaan sampingan & 74,7 \\
8 & Merasa penghasilan keluarga cenderung lebih kecil dari pengeluaran & 87,4 \\
9 & Terpaksa berhutang untuk memenuhi kebutuhan material (perabotan rumah) & 66,7 \\
10 & Merasa perlu menghemat pengeluaran & 89,7 \\
11 & Mengalami kesulitan keuangan & 92,0 \\
\hline
\end{tabular}

membeli pangan. Hampir tiga perempat contoh merasa penghasilan keluarga semakin menurun dan tidak mencukupi kebutuhan keluarga. Bahkan ditengah tidak adanya kesempatan untuk memilih pekerjaan, empat dari sepuluh contoh merasa kurang puas dengan pekerjaan suami saat ini dan dalam jumlah yang sama, contoh juga kecewa dengan ketidakmampuan suami dalam mencari penghasilan.

\section{Manajemen Keuangan}

Pada dasarnya pengelolaan keuangan yang dilakukan suatu keluarga akan berbeda dengan yang dilakukan keluarga lainnya karena kondisipembatas-prioritas keuangan antar keluarga berbeda. Manajemen keuangan keluarga dilihat dari kebiasaan contoh dalam membuat perencanaan, menyimpan uang dalam bentuk tabungan, dan mengevaluasi uang yang dibelanjakan. Individu dan keluarga berpendapatan rendah biasanya mempunyai orientasi untuk masa sekarang atau kini saja daripada untuk masa depannya dalam perspektif waktu (Guhardja 1992). Sebaran contoh menurut manajemen keuangan keluarga disajikan pada Tabel 3. 
Tabel 3. Sebaran persentase contoh berdasarkan frekuensi praktek pengelolaan keuangan

\begin{tabular}{clccc}
\hline No & \multicolumn{1}{c}{ Praktek Pengelolaan Keuangan } & Tidak & $\begin{array}{c}\text { Kadang- } \\
\text { kadang }\end{array}$ & Selalu \\
\hline 1 & Merencanakan penggunaan uang setiap bulannya & 46,0 & 35,6 & 18,4 \\
2 & Menghitung perkiraan biaya hidup sehari-hari & 29,9 & 41,4 & 28,7 \\
3 & Merujuk pada rencana sebelum membeli sesuatu & 47,1 & 21,8 & 31,0 \\
4 & Mencatat biaya pengeluaran & 63,2 & 20,7 & 16,1 \\
5 & Menatapkan standar biaya maksimal dalam & 71,3 & 12,6 & 16,1 \\
6 & pengalokasian pengeluaran & 62,1 & 17,2 & 20,7 \\
7 & Merusaha menabung/mengikuti arisan & 81,6 & 8,0 & 10,3 \\
8 & Mengevaluasi pengeluaran secara rutin dan menyeluruh & 65,5 & 18,4 & 16,1 \\
9 & Membandingkan penerimaan pengeluaran & 37,9 & 36,8 & 25,3 \\
10 & Membicarakan masalah keuangan dengan suami & 10,3 & 13,8 & 75,9 \\
\hline
\end{tabular}

Tabel 3 menunjukkan bahwa hanya sebagian kecil contoh yang telah melaksanakan prinsip-prinsip umum pengelolaan keuangan keluarga. Walaupun sekitar empat dari sepuluh contoh belum merencanakan penggunaan uang setiap bulan dan pengeluaran merujuk pada rencana sebelum membeli sesuatu, namun persentase sisanya lebih besar (60\%) yaitu kadangkadang dan selalu melakukan kedua hal tersebut. Masalah keuangan merupakan hal yang dibicarakan oleh tiga perempat contoh.

Penggunaan catatan pengeluaran akan mempermudah untuk memahami apa yang terjadi dengan uang yang dimiliki dan untuk tujuan apa uang tersebut digunakan. Catatan pengeluaran juga dapat membantu untuk mengontrol pengeluaran keuangan keluarga. Kebiasaan mencatat pengeluaran jarang dilakukan masyarakat atau keluarga Indonesia, terutama jika keuangan yang sangat terbatas dan masih cukup untuk diingat. Oleh karenanya, menarik untuk dielaborasi lebih lanjut mengingat terdapat $37 \%$ contoh yang kadangkadang bahkan selalu melakukan hal tersebut.

Menabung atau investasi merupakan salah satu usaha untuk merencanakan kehidupan keluarga di masa mendatang. Lebih dari separuh keluarga contoh $(62,1 \%)$ menyatakan tidak pernah menabung ataupun mengikuti arisan. Individu dan keluarga berpendapatan rendah akan mengalokasikan keuangannya untuk memenuhi kebutuhan pokok yang lebih besar.

Terbatasnya keuangan keluarga dan terbatasnya tindakan pilihan untuk menggunakan uang, menyebabkan pengelolaan keuangan menjadi sederhana. Hal tersebut ditunjukkan dari lebih dari dua pertiga contoh yang tidak pernah menetapkan standar biaya maksimal dalam pengalokasian pengeluaran, masih sedikit contoh yang memisahkan uang sesuai peruntukkannya, dan hampir dua pertiga keluarga contoh tidak mengevaluasi pengeluaran secara rutin dan menyeluruh. Namun demikian, hampir dua pertiga contoh mempunyai frekuensi kadang-kadang dan selalu dalam hal membandingkan penerimaan dengan pengeluaran.

\section{Mekanisme Koping}

Suatu keluarga yang berpendapatan rendah tentunya akan sulit memenuhi seluruh kebutuhan keluarga. Menurut Mardiharini (2001), strategi yang paling efektif dipilih keluarga dalam menyikapi dampak krisis adalah mengurangi pengeluaran untuk makanan dan non makanan serta meningkatkan produktivitas usaha.

Mengurangi Pengeluaran. Mekanisme koping dengan mengurangi pengeluaran dibedakan menjadi pengeluaran pangan dan nonpangan. Sebaran keluarga contoh menurut mekanisme koping mengurangi pengeluaran pangan disajikan pada Tabel 4.

Pangan adalah kebutuhan pokok yang harus dicukupi setiap hari dan bervariasi antara satu keluarga dengan keluarga lainnya. Pada batas tertentu, pengeluaran pangan tidak bisa dikurangi lagi, baik jumlah maupun jenisnya. Bahkan jika perlu, keluarga meminjam 
Tabel 4. Sebaran persentase contoh berdasarkan mekanisme koping mengurangi pengeluaran pangan

\begin{tabular}{lrrrr}
\hline \multicolumn{1}{c}{ Bentuk koping } & $\begin{array}{c}\text { Tidak } \\
\text { pernah }\end{array}$ & $\begin{array}{c}\text { 1xl } \\
\text { minggu }\end{array}$ & $\begin{array}{c}\text { 2-5xl } \\
\text { minggu }\end{array}$ & $\begin{array}{c}\text { Setiap } \\
\text { hari }\end{array}$ \\
\hline Mengurangi pembelian kebutuhan pangan & 35,6 & 27,6 & 18,4 & 18,4 \\
Mengganti beras dengan makanan pokok lain & 90,8 & 5,7 & 3,4 & 0,0 \\
Mengurangi frekuensi makan & 85,1 & 5,7 & 5,7 & 3,4 \\
Mengurangi penggunaan teh/kopi/gula & 60,9 & 13,8 & 10,3 & 14,9 \\
Mengurangi jajan anak & 77,0 & 3,4 & 11,5 & 8,0 \\
Membawa bekal saat kerja & 20,7 & 3,1 & 5,7 & 70,1 \\
Menyimpan makanan yang tidak habis untuk & 34,5 & 2,3 & 14,9 & 48,3 \\
keesokan harinya & & & &
\end{tabular}

uang atau berhutang untuk membeli pangan. Penelitian ini menunjukkan bahwa sepertiga contoh mengaku tidak mengurangi pengeluaran pangan sebagai salah satu mekanisme koping masalah keuangan keluarga. Hal senada ditunjukkan oleh sebagian besar contoh yang tidak pernah mengganti beras sebagai makanan pokok dan tidak pernah mengurangi frekuensi makan. Konsumsi sumber karbohidrat yang memadai sangat dibutuhkan bagi para buruh karena merupakan modal untuk bisa bekerja.

Mekanisme lain yang banyak dilakukan oleh contoh adalah membawa bekal saat bekerja dan menyimpan makanan yang tidak habis. Lebih dari tiga perempat contoh tidak mengurangi jajan anak karena terkadang makanan jajanan berfungsi sebagai makanan tambahan bagi anak yang ditinggalkan kerja oleh contoh. Separuh contoh tidak mengurangi penggunaan teh/kopi/gula, sebagaimana kebiasaan masyarakat Priangan yang jarang minum air putih.

Selain mengurangi pengeluaran pangan, keluarga contoh melakukan mekanisme koping dengan pengeluaran nonpangan (Tabel 5). Masing-masing tiga perempat contoh memilih tempat berobat yang murah dan mengganti obat yang mahal dengan yang murah. Sementara itu, lebih dari separuh keluarga contoh mengurangi pembelian rokok dan hampir separuh keluarga contoh menggunakan jamu sebagai pengganti obat modern.

Tabel 5. Sebaran persentase keluarga contoh berdasarkan mekanisme koping mengurangi pengeluaran nonpangan

\begin{tabular}{lrr}
\hline \multicolumn{1}{c}{ Aspek/ltem Pengukuran } & Ya & Tidak \\
\hline Kesehatan & & \\
Mengganti obat yang mahal dengan yang murah & 77,0 & 23,0 \\
Menggunakan jamu daripada obat modern & 41,4 & 58,6 \\
Mengurangi pembelian rokok & 54,0 & 46,0 \\
Memilih tempat berobat yang murah & 74,7 & 25,3 \\
& & \\
Pendidikan & & \\
Mengurangi uang saku anak sehari-hari & 19,5 & 80,5 \\
Anak berhenti sekolah & 16,1 & 83,9 \\
Membeli seragam bekas & 12,6 & 87,4 \\
Membeli sepatu bekas & 9,2 & 90,8 \\
& \multicolumn{2}{|c}{} \\
Pengeluaran Lainnya & \multicolumn{2}{c}{} \\
Mengurangi penggunaan air/listrik/telepon & 43,7 & 56,3 \\
Mengurangi pembelian pakaian & 70,1 & 29,9 \\
Mengurangi pembelian perabot rumah tangga & 64,4 & 35,6 \\
Mengurangi pembelian peralatan dapur & 66,7 & 33,3 \\
\hline
\end{tabular}


Penelitian ini menunjukkan bahwa hanya sedikit keluarga mengurangi pengeluaran pendidikan karena biaya pendidikan sudah ada standarnya. Seperlima contoh mengaku mengurangi uang saku anak sehari-hari. Hanya sedikit contoh yang mengaku membeli seragam dan atau sepatu bekas untuk anak sekolah karena pada umumnya anak sekolah berganti baju atau sepatu dalam jangka waktu yang lama. Selain itu, mengurangi pembelian pakaian, perabot rumah tangga, dan peralatan dapur dilakukan oleh sekitar dua pertiga contoh. Kondisi itulah yang menyebabkan sangat sederhananya kondisi peralatan dapur dan perabotan rumah tangga keluarga pemetik teh wanita di lokasi penelitian. Dari tiga kategori pengeluaran, urutan yang menjadi tumpuan mekanisme koping keuangan keluarga adalah mengurangi pengeluaran untuk kesehatan (dilakukan oleh 41-77\% contoh), mengurangi pengeluaran lainlain (dilakukan oleh $43-70 \%$ contoh), dan mengurangi pengeluaran untuk pendidikan (hanya dilakukan oleh 9-19\% contoh).

Menambah Pendapatan. Menambah pendapatan keluarga merupakan jalan keluar yang diharapkan oleh keluarga terutama ketika mengalami kesulitan keuangan dan atau ketika pendapatan utama keluarga tidak mencukupi. Keluarga bisa menggunakan sumberdaya baik yang dimiliki atau yang dapat diakses keluarga untuk menambah pendapatan, seperti memanfaatkan sisa waktu bekerja untuk mencari tambahan pendapatan. Seluruh anggota keluarga bisa diberdayakan untuk mencari penghasilan, bahkan termasuk anakanak. Selain itu, keluarga bisa memanfaatkan halaman pekarangan untuk ditanami tanaman pangan atau obat-obatan, juga ternak unggas dan ikan yang dapat dijual.

Tabel 6 menunjukkan hanya sebagian kecil contoh yang melakukan mekanisme koping dengan menambah pendapatan. Sebagian kecil keluarga contoh (32,2\%) memanfatkan lahan kosong untuk menanam tanaman (jagung, ubi dan singkong). Sementara itu, keluarga contoh yang meningkatkan pendapatan dengan cara beternak unggas dan ikan sebanyak $16,1 \%$ dan $24,1 \%$. Masih sedikitnya contoh yang memanfaatkan lahan pekarangannya untuk menambah pendapatan terutama dikarenakan contoh menempati perumahan dari perkebunan. Oleh karenanya, walaupun menempati rumah tersebut dalam waktu lama, namun pada umumnya contoh tidak merasa memiliki dan memanfaatkan ruang yang ada untuk menambah pendapatan. Alasan lainnya adalah karena terbatasnya luas halaman rumah untuk ditanami tanaman yang menghasilkan, namun masih bisa dipakai untuk memelihara ayam.

Tabel 6. Sebaran persentase keluarga contoh berdasarkan mekanisme koping menambah pendapatan

\begin{tabular}{clrr}
\hline No & \multicolumn{1}{c}{ Bentuk Koping } & \multicolumn{1}{c}{ Ya } & \multicolumn{1}{c}{ Tidak } \\
\hline 1 & Memanfaatkan lahan kosong untuk menanam tanaman pangan & 32,2 & 67,8 \\
2 & untuk dijual & 16,1 & 83,9 \\
3 & Beternak unggas & 24,1 & 75,9 \\
4 & Anak bekerja/membantu orang tua untuk menambah keperluan & 9,2 & 90,8 \\
5 & sekolah & 9,2 & 90,8 \\
6 & Sontoh memiliki pekerjaan sampingan selain pemetik & 16,1 & 83,9 \\
7 & Suami mergiliki pekerjaan sampingan selain pekerjaan utama & 11,5 & 88,5 \\
8 & Contoh/suami Berjualan untuk menambah penghasilan & 6,9 & 93,1 \\
9 & Mengontrakkan rumah untuk menambah keuangan keluarga & 3,4 & 96,6 \\
10 & Menggadaikan barang-barang untuk kebutuhan sehari-hari & 2,3 & 97,7 \\
11 & Menjual barang-barang untuk kebutuhan sehari-hari, & 9,2 & 90,8 \\
12 & Menjual tanah untuk keperluan keluarga & 4,6 & 95,4 \\
13 & Keluarga beternak sapi & 4,6 & 95,4 \\
14 & Keluarga beternak kambing & 4,6 & 95,4 \\
\hline
\end{tabular}




\section{Kesejahteraan Keluarga}

Keluarga menurut Undang-undang Nomor 10 Tahun 1992 adalah keluarga yang dibentuk berdasarkan atas perkawinan yang sah, mampu memberikan kebutuhan hidup spiritual dan material yang layak, selaras dan seimbang antara anggota, antara keluarga dengan masyarakat dan lingkungan. Setiap keluarga memaknai kesejahteraan secara unik, melibatkan perbandingan kondisi ekonomi dengan lingkungan sekitarnya serta meliputi nilai kepuasan terhadap pemenuhan kebutuhan pokok sehari-hari. Menurut Rambe et al. (2008), persepsi keluarga menentukan tingkat kesejahteraannya. Sebaran contoh menurut indikator kesejahteraan disajikan pada Tabel 7 .

Tabel 7. Sebaran persentase contoh menurut indikator kesejahteraan keluarga

\begin{tabular}{|c|c|c|c|}
\hline No & Ukuran Kesejahteraan & Ya & tidak \\
\hline 1 & $\begin{array}{l}\text { Frekuensi makan } \\
\text { utama } 3 \text { kali dalam } \\
\text { sehari (kuantitas } \\
\text { konsumsi) }\end{array}$ & 57,5 & 42,5 \\
\hline 2 & $\begin{array}{l}\text { Makan buah setiap hari } \\
\text { (kualitas konsumsi) }\end{array}$ & 1,1 & 98,9 \\
\hline 3 & $\begin{array}{l}\text { Membeli pakaian sekali } \\
\text { setahun }\end{array}$ & 94,8 & 5,7 \\
\hline 4 & $\begin{array}{l}\text { Mampu } \\
\text { menyekolahkan anak } \\
\text { usia sekolah }\end{array}$ & 64,4 & 35,6 \\
\hline 5 & $\begin{array}{l}\text { Puas dengan makanan } \\
\text { yang dimakan }\end{array}$ & 97,7 & 2,3 \\
\hline 6 & $\begin{array}{l}\text { Puas dengan pakaian } \\
\text { yang dimiliki }\end{array}$ & 88,5 & 11,5 \\
\hline 7 & $\begin{array}{l}\text { Puas dengan rumah } \\
\text { yang ditempati }\end{array}$ & 92,0 & 8,0 \\
\hline 8 & $\begin{array}{l}\text { Puas dengan barang- } \\
\text { barang yang dimiliki } \\
\text { keluarga }\end{array}$ & 41,4 & 58,6 \\
\hline 9 & $\begin{array}{l}\text { Mampu membelikan } \\
\text { mainan untuk anak- } \\
\text { anak }\end{array}$ & 35,6 & 64,4 \\
\hline 10 & $\begin{array}{l}\text { Mampu mencukupi } \\
\text { barang-barang yang } \\
\text { diinginkan keluarga }\end{array}$ & 24,1 & 75,9 \\
\hline 11 & $\begin{array}{l}\text { Mampu membeli } \\
\text { perabotan rumah } \\
\text { tangga yang layak }\end{array}$ & 27,6 & 72,4 \\
\hline 12 & $\begin{array}{l}\text { Mampu membeli } \\
\text { membeli alat } \\
\text { transportasi untuk } \\
\text { keluarga }\end{array}$ & 31,0 & 69,0 \\
\hline 13 & $\begin{array}{l}\text { Mampu membeli } \\
\text { perhiasan atau barang- } \\
\text { barang berharga } \\
\text { lainnya }\end{array}$ & 23,0 & 77,0 \\
\hline
\end{tabular}

Lebih dari separuh contoh mempunyai kebiasaan makan utama tiga kali dalam sehari, namun hampir setengahnya hanya makan dua kali sehari. Hal tersebut tidak sepenuhnya mencerminkan kekurangan, namun karena sudah menjadi kebiasaan masyarakat pedesaan Sunda yang bekerja di pertanian hanya makan dua kali sehari. Hampir seluruh contoh tidak makan buah setiap hari dan hanya membeli pakaian sekali setahun. Hampir dua pertiga contoh menyatakan mampu menyekolahkan anak usia sekolah mereka. Selain itu, sebagian besar contoh juga merasa puas dengan makanan yang dikonsumsi, dengan pakaian yang dimiliki, dan rumah yang ditempati. Sementara itu, lebih dari separuh keluarga contoh merasa tidak puas dengan barang-barang yang dimiliki keluarga.

Sebagian besar daya beli keluarga contoh masih tergolong rendah. Hampir dua pertiga keluarga contoh menyatakan tidak mampu membelikan mainan untuk anak-anak dan tiga perempat contoh tidak mampu mencukupi barang-barang yang diinginkan keluarga. Sementara itu, terdapat tiga persepuluh contoh yang mampu membeli sepeda motor dengan angsuran kredit karena belakangan ini banyaknya penawaran kendaraan motor dengan sistem kredit dengan pembayaran cicilan per bulan sekitar Rp 500.000,00. Motor tersebut umumnya digunakan untuk usaha ojek, sebagai upaya menambah pendapatan suami atau untuk kegiatan usaha anak laki-laki yang sudah besar.

\section{Hubungan Karakteristik Keluarga dengan Tekanan Ekonomi Keluarga, Mekanisme Koping, dan Manajemen Keuangan}

Tabel 8 menunjukkan sebaran koefisien korelasi antara karakteristik keluarga dengan tekanan ekonomi, manajemen keuangan, dan mekanisme keuangan keluarga. Walaupun uji korelasi belum menunjukkan arah hubungan, namun hasil tersebut dapat dimaknai bahwa semakin besar jumlah anggota keluarga semakin besar tekanan ekonomi keluarga. Tekanan ekonomi objektif berkorelasi dengan usia contoh, usia suami dan pendidikan suami. Pendidikan yang tinggi memungkinkan memiliki 
keterampilan yang lebih baik dan lebih dipandang sehingga lebih dipilih untuk mengisi kesempatan bekerja manakala terjadi keterbatasan. Usia yang semakin meningkat memungkinkan keluarga memiliki tabungan atau sebagian anak sudah mandiri sehingga masalah keuangan keluarga semakin berkurang.

Terdapat hubungan yang nyata positif antara pendidikan contoh dengan manajemen keuangan keluarga dan hubungan nyata negatif antara usia contoh dengan mekanisme pengeluaran pangan dan pengeluaran nonpangan. Semakin tinggi pendidikan contoh, memungkinkan contoh memiliki kemampuan pengelolaan keuangan yang lebih baik. Usia contoh maupun suami yang semakin tinggi memungkinkan jumlah tanggungan yang semakin besar dan atau memungkinkan keluarga memiliki tabungan dan aset, dan atau semakin memantapkan pendapatan dan pengeluaran keluarga, sehingga tidak menunjukkan mekanisme koping yang dinamis.

\section{Hubungan antara Tekanan Ekonomi Keluarga dengan Mekanisme koping Sebaran koefisien korelasi Spearman antara mekanisme koping}

dengan tekanan ekonomi keluarga ditunjukkan pada Tabel 9. Terdapat hubungan antara tekanan ekonomi subjektif dengan mekanisme koping mengurangi pengeluaran nonpangan. Semakin tinggi persepsi contoh mengenai tekanan ekonomi yang dirasakan maka semakin tinggi mekanisme koping berupa mengurangi pengeluaran nonpangan.

Hubungan Karakteristik Keluarga dengan Kesejahteraan Keluarga

Hasil uji korelasi (Tabel 10) menunjukkan bahwa kesejahteraan keluarga berkorelasi negatif dengan besar keluarga. Keluarga dengan jumlah anggota yang lebih sedikit tentunya memiliki beban tanggungan dan pengeluaran yang lebih sedikit pula untuk mencukupi kebutuhan keluarga dibanding dengan keluarga yang memiliki anggota keluarga yang lebih besar. Konsisten dengan hasil korelasi lainnya, contoh dan atau suami yang berpendidikan lebih baik mampu mengelola keuangan yang lebih baik, sehingga pendidikan yang lebih baik memungkinkan keluarga dapat meraih kesejahteraan yang lebih baik.

Tabel 8. Koefisien korelasi antara karakteristik keluarga dengan tekanan ekonomi, manajemen keuangan, dan mekanisme koping keluarga

\begin{tabular}{lrrrrr}
\hline \multicolumn{1}{c}{ Peubah } & \multicolumn{5}{c}{ Peubah Karakteristik Keluarga } \\
\cline { 2 - 6 } & \multicolumn{1}{c}{$\mathbf{1}$} & $\mathbf{2}$ & \multicolumn{1}{c}{$\mathbf{3}$} & \multicolumn{1}{c}{$\mathbf{4}$} & $\mathbf{5}$ \\
\hline Tekanan Ekonomi Objektif & 0,156 & 0,094 & $-0,230\left(^{*}\right)$ & $-0,240\left(^{*}\right)$ & $-0,261\left(^{*}\right)$ \\
Tekanan Ekonomi subjektif & 0,152 & $-0,111$ & $-0,166$ & $-0,233\left(^{*}\right)$ & $-0,099$ \\
Tekanan Ekonomi Total & $0,303\left(^{* *}\right)$ & $-0,106$ & 0,034 & $-0,191$ & $-0,126$ \\
Manajemen Keuangan Keluarga & 0,010 & $0,342\left(^{* *}\right)$ & 0,193 & $-0,081$ & $-0,085$ \\
Mengurangi Pengeluaran Pangan & $-0,159$ & 0,109 & 0,108 & $-0,267\left(^{*}\right)$ & $-0,173$ \\
Mengurangi Pengeluaran Nonpangan & $-0,063$ & $-0,031$ & $-0,060$ & $-0,295\left(^{* *}\right)$ & $-0,289\left(^{* *}\right)$ \\
Menambah Pendapatan & 0,113 & $-0,089$ & $-0,191$ & 0,104 & 0,100 \\
Mekanisme Koping Total & $-0,076$ & 0,098 & 0,034 & $-0,196$ & $-0,187$ \\
\hline
\end{tabular}

Keterangan : ${ }^{*} \quad=$ signifikan pada $\alpha=0,05$

** $\quad=$ signifikan pada $\alpha=0,01$

Tabel 9. Koefisien korelasi antara mekanisme koping dengan tekanan ekonomi keluarga

\begin{tabular}{lcccc}
\hline \multicolumn{1}{c}{ Variabel } & $\begin{array}{c}\text { Mengurangi } \\
\text { Pengeluaran } \\
\text { pangan }\end{array}$ & $\begin{array}{c}\text { Mengurangi } \\
\text { Pengeluaran } \\
\text { Nonpangan }\end{array}$ & $\begin{array}{c}\text { Menambah } \\
\text { Pendapatan }\end{array}$ & $\begin{array}{c}\text { Mekanisme } \\
\text { Koping } \\
\text { Total }\end{array}$ \\
\hline Tekanan Ekonomi Objektif & 0,098 & 0,101 & $-0,089$ & $-0,055$ \\
Tekanan Ekonomi Subjektif & 0,032 & $0,273\left(^{*}\right)$ & $-0,028$ & 0,135 \\
Tekanan Ekonomi Keluarga & 0,037 & 0,196 & 0,026 & 0,050 \\
\hline
\end{tabular}

Keterangan : $\quad{ }^{*}=$ signifikan pada $\alpha=0,05$, 


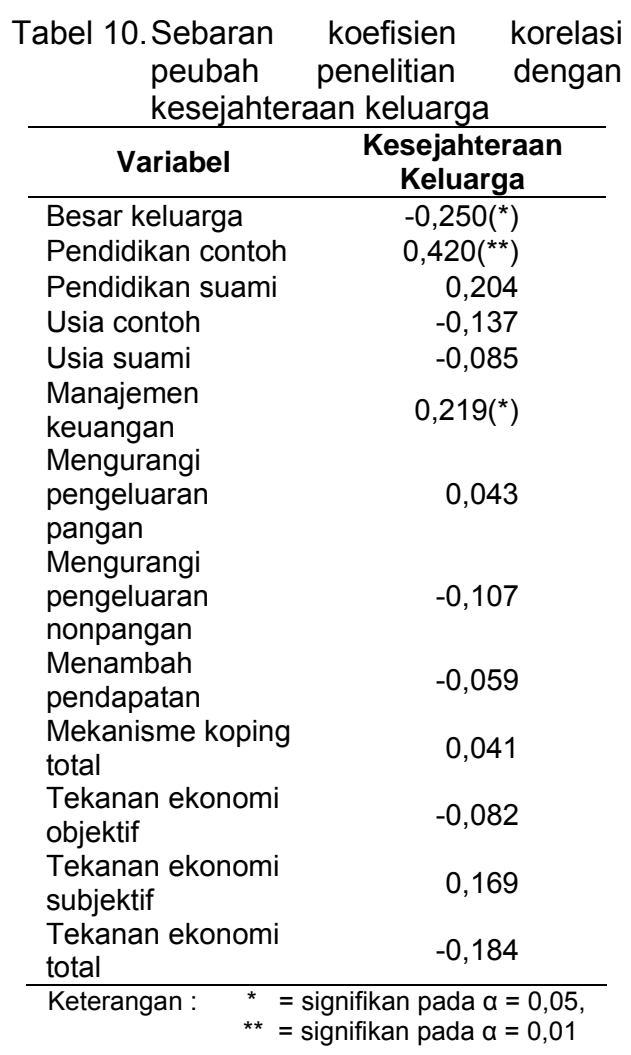

\section{KESIMPULAN DAN SARAN}

\section{Kesimpulan}

Penelitian ini menunjukkan hubungan yang konsisten dan bermakna antar berbagai peubah penelitian. Peubah karakteristik keluarga yaitu besar keluarga serta pendidikan dan usia contoh maupun suami, secara konsisten berkorelasi dengan manajemen keuangan dan mekanisme koping keluarga. Walaupun nilai korelasi belum menunjukkan arah hubungan, namun hasil analisis dapat memberikan beberapa makna utama, yaitu bahwa semakin besar ukuran keluarga, semakin tinggi tekanan ekonomi, dan semakin menurun kesejahteraan keluarga; semakin tinggi pendidikan contoh, semakin baik manajemen keuangan, dan semakin tinggi kesejahteraan keluarga; demikian pula semakin muda usia contoh, semakin tinggi tekanan ekonomi objektif dan tekanan ekonomi subjektif, dan semakin tinggi mekanisme koping baik berupa pengurangan pengeluaran pangan maupun pengeluaran nonpangan.
Saran

Berdasarkan temuan penelitian, peneliti merekomendasikan kepada beberapa pihak yaitu :

- Penyuluh Lapang Keluarga Berencana diharapkan meningkatkan program KB untuk mewujudkan keluarga kecil sejahtera, mengurangi beban tanggungan keluarga, dan mengurangi tekanan ekonomi keluarga.

- Pemerintah daerah untuk giat meningkatkan perekonomian rakyat, khususnya perluasan peluang kerja bagi kelompok masyarakat yang pendidikannya rendah.

- Pengelola program PKK maupun Darma Wanita perusahaan untuk menghidupkan kembali kegiatannya, terutama dukungan dan bantuan pendidikan informal manajemen sumberdaya keluarga, khususnya bagi buruh dan kelompok masyarakat miskin.

- Perlu dilakukan penelitian yang sama terhadap buruh dan pekerja kelas bawah di berbagai bidang pekerjaan dan seluruh wilayah di Indonesia, sehingga dapat dihasilkan generalisasi kesimpulan dan rekomendasi program ketahanan dan kesejahteraan keluarga yang lebih spesifik.

\section{DAFTAR PUSTAKA}

[Anonim]. 1992. Undang-undang Nomor 10 Tahun 1992 Tentang: Perkembangan Kependudukan dan Pembangunan Keluarga Sejahtera.

[BPS] Badan Pusat Statistik. 2007. Perkembangan Tingkat kemiskinan di Jawa barat Tahun 2007. BPS Propinsi Jawa Barat.

Guhardja S, Puspitawati H, Hartoyo, Martianto DH. 1992. Diktat manajemen sumberdaya keluarga. Bogor: Departemen Gizi Masyarakat dan Sumberdaya Keluarga, Fakultas Pertanian, Institut Pertanian Bogor.

Lorenz FO, Conger SD, Montague R. 1994. Doing worse and feeling worse; psychologycal consequences of economic hardship. Dalam: Conger DR, Elder GH, Lorenz FOJr, Simon RL, Whitbeck LB, editor. Families in Troubled Times: Adapting to Change Rural America. Ed ke-8. New York: Aldine De Cruyter. 
Mangkuprawira S. 2002. Analisis keluarga di daerah industri tenun pedesaan. Media Gizi dan Keluarga 26: $72-83$

Mardiharini. 2001. Family-coping strategies in maintaining welfare during the economic crisis in Indonesia: a case study in rural and urban areas in Bogor, West Java, Indonesia. www.litbang.deptan.com. [3 Juni 2008].

Rambe A, Hartoyo, Emmy SK. 2008. Analisis alokasi pengeluaran dan tingkat kesejahteraan keluarga (studi di Kecamatan Medan Kota, Sumatera Utara). Jurnal IImu Keluarga dan Konsumen 1:16-28.
Sunarti E. 2001. Kajian ketahanan keluarga: pengembangan alat ukur dan analisis pengaruhnya terhadap kualitas perkawinan [disertasi]. Bogor: Program Pascasarjana, Institut Pertanian Bogor. . 2008. A study of plantation women workers; socio economic status, family strength, food consumption, children growth and development [laporan]. Bogor: Departemen IImu Keluarga dan Konsumen, Fakultas Ekologi Manusia, Institut Pertanian Bogor.

Sunarti E, Tati, Atat SN, Noorhaisma R, Lembayung DP. 2005. Pengaruh tekanan ekonomi keluarga, dukungan sosial, kualitas perkawinan, pengasuhan dan kecerdasan emosi anak terhadap prestasi belajar anak. Media Gizi dan Keluarga 29:34-40.

\footnotetext{
Korespondensi :

Departemen IImu Keluarga dan Konsumen

Fakultas Ekologi Manusia IPB

Jl. Lingkar Kampus IPB Dramaga 16680

Telp : +62-2518628303

Email: euisnm@gmail.com
} 